\title{
Microbial Mobilization of Plutonium and other Actinides from Contaminated Soil
}

\author{
A.J. Francis* and C.J. Dodge \\ Biological, Environmental \& Climate Sciences Department, Brookhaven National Laboratory \\ Upton, NY 11973 USA
}

ABSTRACT

We examined the dissolution of $\mathrm{Pu}, \mathrm{U}$, and $\mathrm{Am}$ in contaminated soil from the Nevada

9 Test Site (NTS) due to indigenous microbial activity. Scanning transmission x-ray microscopy

10 (STXM) analysis of the soil showed that $\mathrm{Pu}$ was present in its polymeric form and associated

11 with aluminosilicates. Uranium analysis by $\mathrm{x}$-ray diffraction ( $\mu$-XRD) revealed discrete U-

12 containing mineral phases, viz., schoepite, sharpite, and liebigite; synchrotron x-ray fluorescence

13 ( $\mu$-XRF) mapping showed its association with Fe- and Ca-phases; and $\mu$-X-ray absorption near

14 edge structure ( $\mu$-XANES) confirmed U(IV) and U(VI) oxidation states. Addition of citric acid

15 or glucose to the soil and incubated under aerobic or anaerobic conditions enhanced indigenous

16 microbial activity and the dissolution of Pu. Detectable amount of Am and no U was observed in

17 solution. In the citric acid-amended sample, Pu concentration increased with time and decreased

18 to below detection levels when the citric acid was completely consumed. In contrast, with

19 glucose amendment, Pu remained in solution. Pu speciation studies suggest that it exists in mixed

20 oxidation states (III/IV) in a polymeric form as colloids. Although $\mathrm{Pu}(\mathrm{IV})$ is the most prevalent

21 and generally considered to be more stable chemical form in the environment, our findings

22 suggest that under the appropriate conditions, microbial activity could affect its solubility and

23 long-term stability in contaminated environments.

Keywords: Plutonium, Uranium, Americium, Microbial activity, Actinides contaminated soil, Actinide dissolution and speciation

* Corresponding author phone: (631) 344-4534; francis1@ bnl.gov 


\section{Introduction}

The presence of low levels of plutonium $(\mathrm{Pu})$ in contaminated soils and at remediated

33 sites is a major concern because of its potential for dissolution and mobilization in the

34 environment. Primary worries center on plutonium's toxicity, and the relatively long half-lives of

35 its isotopes $\left(87.7-8.0 \times 10^{8} \mathrm{y}\right)$. Nuclear weapons testing at the Nevada Test Site (NTS) during

36 the 1950s and early 1960s have resulted in the contamination of large area of soil with plutonium

37 and other radionuclides at levels in excess of $40 \rho \mathrm{Ci}$ per gram. The bulk of the activity typically

38 resides within the top few centimeters of the soil; the primary radionuclides of concern are

39 plutonium, uranium, and americium, with lesser amounts of cesium, strontium, and europium

40 (Walker and Liebendorfer 1998). Studies of the soils at the NTS's Area 11 demonstrated that

41 more than $75 \%$ of the total radionuclides are dispersed as particles in the 40 -micron soil fractions

42 (Papelis, et al. 1996), and/or are partially attached to clay particles. The plutonium particles are

43 relatively immobile and expected to remain so until disturbed.

45 was observed at several Department of Energy's sites, and at the Mayak Production Association,

46 Urals, Russia (Kersting, 2013). Thus, Pu was present in colloidal form at Los Alamos National

47 Laboratory's (LANL) waste site (Penrose, et.al. 1990); similarly, at Maxey Flats, a former low-

48 level radioactive waste site, $\mathrm{Pu}$ occurred as colloids, as well as soluble tetravalent species

49 complexed with organic ligands (Cleveland, and Rees, 1981). At Mayak, it was bound to iron-

50 oxide colloids (Noviko, et al. 2006). The predominant form of $\mathrm{Pu}$ in the soil at Rocky Flats, CO,

51 was $\mathrm{PuO}_{2}$ (s) (Clark, et al. 2006), while, in surface waters, it existed as colloids associated with

52 organic macromolecules (Santschi, et al. 2002; Xu, et al.; 2008). At three other disposal sites, Pu

53 formed similar associations: at the Hanford site, $\mathrm{Pu}$ (III/IV) was associated with colloids in the 
54 groundwater at the 100K-Area (Dai, et al. 2005); at the Savannah River Site, it was detected in

55 combination with colloids in groundwater samples near the disposal basins in F-Area (Buesseler,

56 et al. 2009); and, at the NTS Pu was complexed with mineral colloids (Kersting, et al 1999).

57 Studies at NTS show that the $\mathrm{U}$ and the fission products Sr and Cs also are associated with 58 colloids (Utsunomiya, et al. 2009).

59 Microorganisms were detected in low-level radioactive- and TRU- wastes, in $\mathrm{Pu}$ 60 contaminated soils, and in waste-repository sites under consideration for nuclear-waste disposal 61 (Au and Leavitt, 1982; Barnhart, et al. 1980; Johnson; et al. 1974; Francis, 1990; 2001;. 2007).

62 Microbiological studies at the NTS showed the presence of bacteria and fungi in Area 13 soils 63 (Au and Leavitt, 1982), and bacteria in the subsurface environments at the Rainier Mesa, in 64 oxygenated volcanic tuff, and in groundwater (Amy, et al.1992; Haldeman, and Amy, 1993; 65 Horn, et al. 2004). Microbes may affect the solubility and mobility of Pu (Francis, 2001; Neu, et 66 al. 2005; Boukhalfa, et al. 2007; Francis, et al. 2008; Renshaw et al. 2009).

67 Several studies have shown that bacteria and fungi play a major role in the dissolution of $68 \mathrm{PuO}_{2}$, amorphous forms of $\mathrm{Pu}(\mathrm{IV}) \mathrm{OH}$, and other chemical forms. Some bacteria and fungi grown 69 in the presence of $\mathrm{Pu}$ produced extracellular $\mathrm{Pu}$ complexes that increased the concentration of $\mathrm{Pu}$ 70 in soil-column eluates compared to controls. Elution through soil effectively removed positively 71 charged $\mathrm{Pu}$ complexes (Wildung, et al. 1987). The increased mobility of $\mathrm{Pu}$ in the soil resulted 72 from the formation of neutral and negatively charged $\mathrm{Pu}$ complexes. In the presence of known 73 microbial metabolites and the synthetic ligands DTPA, EDTA, and EDDHA, Pu(VI) was 74 reduced to $\mathrm{Pu}(\mathrm{IV})$ before complexation, suggesting that the latter valence state would be the 75 dominant one associated with organic complexes in soils (Wildung, and Garland, 1980). Studies 
76 show that biologically produced ligands mediate $\mathrm{Pu}$ transport, such as cutin-derived soil

77 degradation products containing siderophore-like moieties (Xu et al. 2008).

Although a wide variety of microorganisms were detected at the $\mathrm{Pu}$ contaminated sites,

79 very little is known of their effects of microbial activity on the stability and mobility of the

80 actinides in soils and wastes. An increase in moisture and the availability of metabolizable

81 organic carbon in contaminated soils located in arid and semi-arid regions could increase

82 microbial activity. In this study, we investigated the potential effects of indigenous microbial

83 activity on the dissolution of actinides in NTS soil amended with citrate or glucose as carbon

84 sources and incubated under aerobic and anaerobic conditions. Citrate is a naturally-occurring

85 organic compound capable forming stable complexes with actinides and metals. Citrate is readily

86 metabolized soil microorganisms. Glucose an intermediate of cellulose degradation product is

87 metabolized by microorganisms and under anaerobic and water logged conditions results in the

88 accumulation of low molecular weight organic metabolic products such as acids and alcohols.

90 2. Materials and Methods

91

92 2.1. Soil sample. About $100 \mathrm{~g}$ of plutonium-contaminated soil (HP-11) was obtained

93 from Area 11 of the Double Track test shot area at the NTS. Soils at the NTS region are

94 classified as medium- to fine-grained sands (Turner, et al. 2003). The predominant vegetation in

95 the area is the shrub species of basin big sagebrush and black sagebrush (Nevada Test Site

96 Annual Site Environmental Report-2002, DOE/NV/11718-842, 2003). One gram of the soil was

97 transferred to each of three platinum crucibles, was digested with concentrated nitric acid and 
98 analyzed for the metals $\mathrm{Al}, \mathrm{Ba}, \mathrm{Ca}, \mathrm{Cd}, \mathrm{Co}, \mathrm{Cr}, \mathrm{Cu}, \mathrm{Fe}, \mathrm{Mg}, \mathrm{Mn}, \mathrm{Ni}, \mathrm{Pb}, \mathrm{Sr}$, and $\mathrm{Zn}$ by

99 inductively coupled plasma-optical emission spectrometer (ICP-OES).

101 the soil was digested in a mixture of hydrochloric/nitric acid. The U-233/234, U-235/236, U-238,

$102 \mathrm{Am}-241, \mathrm{Pu}-238, \mathrm{Pu}-239 / 240$ and $\mathrm{Pu}-241$ were separated by anion-exchange column

103 chromatography, followed by liquid scintillation counting (LSC) (EML Procedures Manual,

104 HASL-300, 28th Edition, Volumes I and II. 1970).

105 2.3. Mineralogical analysis. The major mineralogical constituents of the soil are clay, 106 quartz, magnetite, titanomagnetite, and limestone (Hoeffner, et al. 2005). The fine fraction 107 consisted of clay, quartz, and feldspar.

108 The minerals present in the soil were determined by $\mathrm{x}$-ray diffraction (XRD) using beam 109 line X7A at the National Synchrotron Light Source (NSLS). The soil was placed on an Al 110 sample holder, and sealed with Kapton tape. The beamline's energy was $0.69850 \AA$, and a $2 \theta$ 111 scan was obtained from 5 to $68^{\circ}$ with a scan rate of $0.02^{\circ}$ per second.

112 The mineralogical association of actinides in the soil was determined using a modified 113 sequential selective-extraction method (Tessier, et al. 1985). Briefly, the soil was extracted with 114 (i) $1 \mathrm{M} \mathrm{MgCl}_{2}$ and $0.05 \mathrm{M}$ citric acid (pH 7) for 1 hour (exchangeable fraction), (ii) an acetate 115 buffer prepared by adjusting a $1 \mathrm{M} \mathrm{NH}_{4}$-acetate solution to $\mathrm{pH} 5$ with acetic acid, adding $0.05 \mathrm{M}$ 116 citric acid, and then agitating the mix for 5 hours (association with carbonate), and, (iii) 25\% 117 acetic acid with $\mathrm{NH}_{2} \mathrm{OH} \cdot \mathrm{HCl}$ for 6 hours (association with $\mathrm{Fe}-$, Mn-oxides). Citric acid was 118 added to the extractant to prevent/minimize actinide precipitation from solution; it had a minimal 119 effect on the extraction of actinides at this $\mathrm{pH}$. The samples were then filtered through a $0.45 \mu \mathrm{m}$ 120 filter before analysis. 
122 in an Al sample holder, and sealed with Kapton tape and analyzed by x-ray absorption near edge

123 spectroscopy ( $\mu$-XANES), and $\mu$-X-ray diffraction ( $\mu$-XRD) at the NSLS's X26A beam line to

124 determine the oxidation state and the mineralogical association of the actinides in the soil.

125 Synchrotron $\mu$-X-ray fluorescence (SXRF) analysis was performed to map the elemental

126 distribution and for determining the association of actinides with the selected elements $\mathrm{Ca}, \mathrm{Cr}$,

$127 \mathrm{Cu}, \mathrm{Fe}, \mathrm{Mn}, \mathrm{Sr}, \mathrm{U}$, and $\mathrm{Zn}$. The Pu-containing particles in the soil was analyzed Synchrotron

128 scanning transmission x-ray microscopy (STXM) at beam line MES 11.0.2 at the Advanced

129 Light Source (ALS).

130 2.5. Extraction of actinides. To compare the leachability of actinides, the alpha- and

131 beta-emitting isotopes were extracted from the soil by water, citric acid, and nitric acid, as

132 follows. Duplicate one gram samples of soil were transferred to $20 \mathrm{ml}$ serum bottles and ten

133 milliliters of the following solutions added: (i) deionized water, (ii) $0.1 \mathrm{M}$ citric acid, or, (iii) $1 \mathrm{M}$

134 nitric acid. The soil samples were agitated on a rotary shaker for three hours. An aliquot was

135 removed for analysis of $\alpha$ and $\beta$ activities in the the unsettled suspension, in the settled

136 supernatant and filtered supernatant. The sample was allowed to settle for $1 \mathrm{~h}$ and the supernatant

137 was filtered through a $0.45 \mu \mathrm{m}$ filter (Millipore, MA). The $\alpha$ and $\beta$ activities determined by

138 liquid scintillation counting (LSC) using a Wallac Guardian 1414 digital spectrum analyzer.

140 of actinides from the soil. To $150 \mathrm{ml}$ Erlenmeyer flasks $40 \mathrm{ml}$ of one of the following solutions

141 (wt. \%) were added: (i) deionized water (unamended), (ii) deionized water containing glucose

$142(0.5 \%)$ and $\mathrm{NH}_{4} \mathrm{NO}_{3}(0.015 \%)$, or, (iii) deionized water containing citrate $(0.5 \%)$ and $\mathrm{NH}_{4} \mathrm{NO}_{3}$

$143(0.015 \%)$. The $\mathrm{pH}$ of the solutions were adjusted to 7 , the flasks were fitted with cotton plugs and 
144 sterilized by autoclaving. One gram of the soil was transferred each of the flasks and the samples

145 in triplicate were incubated aerobically at $26 \pm 1{ }^{\circ} \mathrm{C}$ in the dark, on a shaker rotating at $125 \mathrm{rpm}$.

146 We incubated a second identical set of samples for each treatment, and did not sample them until

147 the end of the experiment for $\mathrm{Pu}$ speciation determination.

148 The anaerobic samples were prepared by transferring $40 \mathrm{ml}$ of the following treatments

149 (wt. \%): (i) deionized water (unamended), (ii) deionized water containing glucose (0.5\%) and

$150 \mathrm{NH}_{4} \mathrm{NO}_{3}(0.015 \%)$, and (iii) deionized water containing citrate $(0.5 \%)$ and $\mathrm{NH}_{4} \mathrm{NO}_{3}(0.015 \%)$

151 into acid-washed and autoclaved $125 \mathrm{ml}$ serum bottles. The solutions prior to addition were

152 adjusted to $\mathrm{pH} 7$ and prereduced by boiling while bubbling nitrogen gas through them. One gram

153 of the soil was added tothe serum bottles containing the various treatments and were then fitted

154 with butyl rubber stoppers and crimp sealed with aluminum caps. All manipulations were

155 performed inside an anaerobic glove bag filled with nitrogen. The soil samples were incubated in

156 the dark, on a rotary shaker at $125 \mathrm{rpm}$ and $26 \pm 1^{\circ} \mathrm{C}$. An identical set of samples from each

157 treatment was incubated but not sampled until the end of the experiment, to determine $\mathrm{Pu}$ 158 speciation.

159 2.7. Chemical analysis. Periodically, a $3.0 \mathrm{ml}$ aliquot was withdrawn, the $\mathrm{pH}$ was 160 determined the sample filtered through a $0.45 \mu \mathrm{m}$ Millex (Millipore, MA) filter, and the total 161 radioactivity in a $1.0 \mathrm{ml}$ aliquot was determined by LSC. Glucose and citrate consumption and 162 the presence of metabolic products were analyzed by HPLC (Shimadzu, LC-10AS) using a 163 refractive index detector to measure glucose and alcohol production, and a UV-vis detector at $164210 \mathrm{~nm}$ for organic acids. The organic components were separated using an Aminex HPX-87H 165 ion-exclusion column (Bio-Rad, MA) with $0.003 \quad \mathrm{~N} \mathrm{H}_{2} \mathrm{SO}_{4}$ as the mobile phase. The 166 solubilization of the alpha-emitting isotopes U-233/234, U-235/236, U-238, Am-241, Pu-238, 
$167 \mathrm{Pu}-239 / 240$, and the beta-emitter Pu-241 were determined by alpha spectroscopy and LSC as 168 described previously.

169 At the end of the experiment, the pressure in the head space of the undisturbed anaerobic 170 samples was determined with a digital pressure transducer, and the $\mathrm{pH}$ and Eh were measured, 171 respectively, with a Beckman $\Phi 350 \mathrm{pH}$ meter with a Beckman 511275-AB combination $\mathrm{pH}$ 172 electrode, and with a combination redox electrode (967800, Orion Research, MA). Total and 173 ferrous iron were determined by the $o$-phenanthroline method.

174 2.8. Pu speciation studies. Size fractionation of Pu on all samples was performed after 175 sequential filtration through $0.4,0.2,0.03,0.01$, and $0.001 \mu \mathrm{m}$ Poretics (CA) polycarbonate 176 filters into a weighed LSC vial using an Amicon (MA) ultrafiltration cell.

177 The sequential solvent-extraction technique was used to determine the oxidation states of $178 \mathrm{Pu}$ in the sample (Nitsche, et al. 1988). The samples were filtered through a $0.45 \mu \mathrm{m}$ Millex 179 filter, and a $0.5 \mathrm{ml}$ aliquot dispensed into a $4 \mathrm{ml}$ silanized glass vial (Sigma-Aldrich, MO) inside 180 a glove bag. To this sample, we added $1.0 \mathrm{ml}$ thenoyltrifluoroacetone (TTA) equilibrated with 1 $181 \mathrm{M} \mathrm{HCl}$, and then extracted the sample for 5 minutes on a vortex mixer. The organic and aqueous 182 extracts were separated, and each then analyzed for Pu by LSC after adding $8 \mathrm{ml}$ of the LSC 183 cocktail. We repeated the extraction on a separate aliquot of the sample in acetate buffer at $\mathrm{pH} 4$.

\section{3. Results}

3.1. Elemental and actinide analyses. Soil analysis revealed the following major 188 elements (mg/kg soil $\pm 1 \mathrm{SEM}): \mathrm{Al}(3890 \pm 100), \mathrm{Ca}(12700 \pm 100), \mathrm{Fe}(6500 \pm 1800), \mathrm{Mg}(223$

$189 \pm 12)$, Mn $(223 \pm 23)$, and $\operatorname{Sr}(133 \pm 4)$, and others $\mathrm{Ba}(89.5 \pm 1.0), \mathrm{Cd}(0.2 \pm 0.1)$, Co $(2.8 \pm$ 
191 elements $\mathrm{Ca}$ and Fe reflect the predominant mineral phases of the soil which have a high affinity 192 for actinides and regulate their mobility.

193 Table 1 shows the alpha activity and the concentration in the soil. The individual alpha194 emitting isotopes (\% total activity): Pu-239/240 (92\%), Pu-238 (0.6\%), and Am-241 (5\%). The 195 total alpha activity in the soil was $<75 \mathrm{nCi} / \mathrm{g}$. Gamma spectroscopy of the bulk soil showed the 196 predominant activity was due to the presence of Am-241 (742 nCi/g), Pu-239 (455 pCi/g), and $197 \mathrm{Pu}-241(1.7 \mathrm{nCi} / \mathrm{g}) .$. Uranium was not detected due to the low specific activity of its isotopes.

198 3.2. Mineralogical association of $\boldsymbol{\alpha}$-activity. Selective extraction of the soil showed a 199 minimal level of $\alpha$ activity $(0.03 \%)$ associated with the exchangeable fraction; about $1 \%$ with the 200 carbonate fraction, and $11 \%$ with the Fe-, Mn- oxide fraction. The bulk of the activity ( 88\%) 201 was associated with the residual fraction (Figure 1).

3.3. Mineralogical association of uranium. The $\mu$-XRD analysis of separate uranium203 containing regions of the soil showed that $\mathrm{U}$ was associated with a schoepite phase $\left(\mathrm{UO}_{3} \cdot 2 \mathrm{H}_{2} \mathrm{O}\right)$ 204 (Figure S1A), and with the carbonate minerals liebigite $\mathrm{Ca}_{2} \mathrm{UO}_{2}\left(\mathrm{CO}_{3}\right)_{3} \cdot 10 \mathrm{H}_{2} \mathrm{O}$ and sharpite $205 \mathrm{Ca}\left(\mathrm{UO}_{2}\right)_{6}\left(\mathrm{CO}_{3}\right)_{5}(\mathrm{OH})_{4} \cdot 6 \mathrm{H}_{2} \mathrm{O}$ (Figure $\mathrm{S} 1 \mathrm{~B}$ ). Elemental mapping by synchrotron $\mu$-X-ray 206 fluorescence analysis showed the spatial association $\left(10 \mu \mathrm{m}^{2}\right)$ of $\mathrm{Ca}$ and $\mathrm{Fe}$ with $\mathrm{U}$ (Figure 2). 207 The Ca-containing phases exhibit the closet correlation and no other elements were correlated 208 with $\mathrm{U}$. The normalized $\mu$-XANES spectra at the $\mathrm{U} \mathrm{L}_{\mathrm{III}}$ absorption edge for the soil sample at the 209 X-26A beam line (NSLS) showed the uranium absorption edge at $17169 \mathrm{eV}$, lying between that 210 of tetravalent uranium (17166 eV) and hexavalent uranium (17171 eV) (Figure 3). This indicates 211 that $\mathrm{U}$ is in a mixed-valence form, most probably as uranium dioxide and $\mathrm{U}(\mathrm{VI})$ compounds. 
213 scanning transmission X-ray microscopy ( $\mu$-STXM) of the soil particles. The boxed region

214 consisted of Fe- and Mn- oxides and aluminosilicates. Plutonium was observed in this region

215 (Figure 4B), and was localized to a small area of the sample $(500 \mathrm{~nm})$.

216 3.5 Extraction of actinides. The total alpha and beta activity of radionuclides extracted

217 from the soil by water, citric acid, and nitric acid is shown in Table 2. The unfiltered suspension

218 showed the highest amount of activity in all three treatments with alpha activity (63 to 98\%)

219 being the largest component. The unfiltered supernate following settling showed a marked 220 decrease in both alpha (70-80\%) and beta (>98\%) activity compared to to the suspension. The

221 activity of the supernatant after $0.45 \mu \mathrm{m}$ filtration showed the least amount of activity in solution

222 indicating that the bulk of the activity was associated with soil particulates larger than $0.45 \mu \mathrm{m}$.

223 The filtered nitric acid extract had the greatest level of alpha activity in the solution (10.8

$224 \mathrm{kcpm} / \mathrm{g})$, followed by citric acid $(7.28 \mathrm{kcpm} / \mathrm{g})$ and water $(0.07 \mathrm{kcpm} / \mathrm{g})$. Beta activity followed a

225 similar pattern; the filtered nitric acid extract had the most activity $(0.48 \mathrm{kcpm} / \mathrm{g})$, then citric acid

$226(0.36 \mathrm{kcpm} / \mathrm{g})$, with the water having the lowest activity $(0.04 \mathrm{kcpm} \mathrm{cpm} / \mathrm{g})$.

228 actinides from the soil. Table 3 shows the changes in $\mathrm{pH}$, Eh, total iron, and $\mathrm{Fe}$ (II) in both

229 aerobic and anaerobic samples, and the changes in pressure in the latter after 36 days of 230 incubation. In unamended samples incubated aerobically, the initial pH of the soil was $~ 8.2$ at

231 the start of the experiment and it increased to 9.0; and in the anaerobic sample to $\mathrm{pH} 9.3$. Eh, an

232 indicator of the sample's redox potential, was oxidizing $(>500)$ in both the aerobic and anaerobic 233 unamended samples. 
In the citrate amended samples incubated aerobically, the pH decreased from 9.0 to 7.7

235 and the Eh from 607 to 170 (Table 3). There was a similar decrease in $\mathrm{pH}$ from 9.3 to 7.4 in the

236 anaerobic samples and the Eh declined markedly to -306 due to the consumption of oxygen and

237 the establishment of reducing conditions. Total iron and ferrous iron were $<0.1 \mathrm{mM}$. No

238 detectable ferrous iron in solution was observed in samples incubated under aerobic and

239 anaerobic conditions. Gas production was not observed in the anaerobic citric acid amended 240 samples.

241 In samples incubated aerobically with glucose the $\mathrm{pH}$ decreased from 9.0 to 5.2 and the

242 Eh to 337 (Table 3). In the glucose amended anaerobic sample, the $\mathrm{pH}$ decreased to 4.8 and the

243 Eh decreased to $-210 \pm 18$, characteristic of highly reducing conditions. The head-space pressure

244 rose to 7 psig due to gas production $\left(\mathrm{CO}_{2}\right.$ and $\left.\mathrm{H}_{2}\right)$ from the metabolism of glucose. The total and

245 the ferrous ion concentrations in solution increased in the anaerobic sample. This increase in

246 total and ferrous iron reflect the reduction of ferric to ferrous iron mostly by the Fe-reducing

247 and/or fermentative bacteria as well as the lower $\mathrm{pH}$ of the solution.

248 Figure 5 depicts the metabolism of citric acid, changes in $\mathrm{pH}$, and total radioactivity in 249 the solution phase of soil incubated aerobically and anaerobically. In addition to these 250 measurements, we determined the $\mathrm{U}, \mathrm{Pu}$, and Am activities, along with the concentrations of $\mathrm{Ca}$, $251 \mathrm{Fe}$, and $\mathrm{Mn}$ in the solution phase of samples incubated anaerobically.

252 Citric acid was metabolized completely in about 17 and 25 days, in the aerobic and 253 anaerobic samples, respectively. Alpha and Beta activity in samples incubated under both 254 conditions increased in solution up to 18 days, and decreased to below detection levels with time, 255 concomitant with the complete metabolism of citric acid (Figure 5A and C). 
257 acid was completely metabolized to carbon dioxide and water with no accumulation of metabolic

258 products (Figure 5B). However, under anaerobic conditions, the $\mathrm{pH}$ decreased to 7.8, and acetic

259 acid was the major metabolic product with minor amounts $(\sim 0.2 \mathrm{mM})$ each of propionic acid

260 and butyric acid were detected (Figure 5D).

261 The concentrations of $\mathrm{Am}, \mathrm{Pu}$, and $\mathrm{U}$, and the metals $\mathrm{Ca}, \mathrm{Fe}$, and $\mathrm{Mn}$ in the aqueous 262 phase are shown in Figure 5E and F. Am-241, Pu-239/240, and Pu 241 increased in solution and 263 precipitated out of solution. Pu-239/240 isotopes were the predominant ones with the highest 264 activity in solution. The concentrations of $\mathrm{Ca}$, and $\mathrm{Fe}$ increased during the initial days due to 265 complexation reactions and precipitated from solution reflecting citric acid metabolism by the 266 bacteria. Very little dissolution of Mn and U was observed (Figure 5F).

267 Glucose was metabolized completely in about 18 days in both aerobic and anaerobic 268 samples (Figure 6A and C). In the aerobic samples the total activity increased to $\sim 108 \mathrm{cpm} / \mathrm{ml}$ at 26936 days and the predominant activity was alpha, which remained in solution. The $\mathrm{pH}$ decreased 270 from 9.2 to 4.8 with the accumulation of acetic as the major product, followed by butyric and 271 propionic acids (Figure 6B). In the anaerobic samples the total activity increased similar to 272 aerobic samples with higher alpha activity (Figure 6C). A slight increase in beta activity was 273 observed as with aerobic samples. The $\mathrm{pH}$ of the medium decreased to 5.5; acetic acid was the 274 predominant metabolite, with small amounts of butyric acid (4.5 mM) and propionic acid (1.0 $275 \mathrm{mM})$ (Figure 6D).

$276 \mathrm{Pu}-239 / 240$ and $\mathrm{Pu}-241$ were the predominant isotopes of $\mathrm{Pu}$ in solution followed by 277 small amount of Am-241 were observed under anaerobic conditions. These actinides remained in 278 solution throughout the incubation unlike the citric acid amended sample (Figure 6E). Uranium 
279 increased to $\sim 1.46 \mu \mathrm{M}$ in solution and it remained almost constant (Figure 6F). The $\mathrm{Ca}$ and $\mathrm{Fe}$

280 concentrations increased to $7.0 \mathrm{mM}$ and $1.29 \mathrm{mM}$, respectively, and the $\mathrm{Mn} 77.1 \mu \mathrm{M}$ in 8 days.

281 Calcium levels started to decrease after 25 days, while a slight change in Mn and no change in Fe

282 in solution were observed. XRD analysis of soil amended with glucose and incubated

283 anaerobically showed fewer peaks compared to the "as received" soil indicating dissolution of

284 some labile mineral phases (Figure S2). Soil before bacterial activity contained calcite, periclase

285 ( $\mathrm{MgO}$ ), dolomite, magnetite, and silicates (quartz, faujasite, labradorite). Calcite, dolomite, and 286 magnetite phases underwent dissolution after anaerobic bacterial activity.

287 3.7. Pu speciation studies. Samples incubated under anaerobic conditions with glucose 288 showed detectable activity in solution phase. Table 4 shows the effect of sequential filtration on 289 alpha and beta activity. Plutonium activity is high in the unfiltered sample due to the presence of 290 suspended particles containing predominantly $\mathrm{Pu}-239$ (alpha activity) and $\mathrm{Pu}-241$ (beta activity).

291 Sequential filtration of the solution from $0.4 \mu \mathrm{m}$ to $0.01 \mu \mathrm{m}$ only marginally attenuated alpha 292 activity (126 to $106 \mathrm{cpm} / \mathrm{ml})$. However, filtrating through the $0.001 \mu \mathrm{m}$ filter reduced this 293 activity by about $50 \%$, indicating the particles were between 0.01 and $0.001 \mu \mathrm{m}$ size. No 294 significant difference was observed for beta activity due to its low activity level in solution. This 295 result suggests the presence of a fine colloidal component that the $0.001 \mu \mathrm{m}$ filter retained and 296 soluble component that the Pu passed through the $0.001 \mu \mathrm{m}$ filter.

297 We also determined the speciation of $\mathrm{Pu}$ by selective solvent extraction and micro298 filtration techniques in glucose amended samples that was left undisturbed under anaerobic 299 conditions for 40 days. A TTA extraction of selected $0.45 \mu \mathrm{m}$ filtered samples showed no 300 discernible difference in the oxidation state of $\mathrm{Pu}$ in either the aerobic or anaerobic glucose 301 amended samples (Table S1). However, we observed a decrease in activity in the TTA extraction 
302 at $\mathrm{pH}$ 4. A brownish colloid was noted in this sample after extraction that might indicate the 303 incomplete separation of the Pu.

\section{Discussion}

The radioactivity in the NTS soil was predominantly due to the presence of $\mathrm{Pu}-239 / 240$ 308 (92\%), Am-241 (5\%), and Pu-238 (0.6\%) isotopes. Uranium was not detected due to the low 309 specific activity of its isotopes; however, synchrotron-based $\mu$-XRF and $\mu$-XRD techniques 310 showed its presence in the soil associated with the minerals schoepite and liebigite. Americium

311 association and the speciation was not investigated however it is known to stick to particles and 312 exist predominantly as Am(III) oxidation state in a stable form in the environment. Plutonium 313 association was correlated with $\mathrm{Fe}$ - and M-oxides and aluminosilicates as particulates. Because 314 of the low concentration of Pu, we could not determine its chemical speciation by XANES, or by 315 the selective solvent-extraction technique. Plutonium can simultaneously coexist in several 316 oxidation states (III, IV, V, VI, VII) and their solution chemistry is very complex. Plutonium

317 (IV) is the most predominant and stable species in contaminated environments. Plutonium has a 318 high ionic charge, and tends to undergo hydrolysis, thereby forming polymers in systems with $319 \mathrm{pH}>2$. Its chemical speciation is affected by soil $\mathrm{pH}$, organic-matter content, mineralogy, 320 microbial activity, and redox conditions.

321 The type of carbon source added to the soil affected the extent of solubilization of 322 actinides. Citric acid is a naturally occurring multidentate ligand that forms stable complexes 323 with actinides, and may involve the formation of bidentate-, tridentate-, binuclear-, or poly324 nuclear species. For example, it forms 1:1 mononuclear, 1:2 mononuclear biligand, and 2:2 
325 binuclear complexes with $\mathrm{Pu}(\mathrm{IV})$; the 1:2 mononuclear biligand complex predominated in the

326 presence of excess citric acid (Francis, et al. 2006). The citric acid was rapidly metabolized by

327 Pseudomonas fluorescens, common in soils, wastes, and water with generation of a Pu polymer

328 (Francis, et al. 2006). Under aerobic and anaerobic conditions both alpha and beta activity in

329 solution increased in citric-acid amended soils; as this organic acid was being metabolized a

330 sudden decrease in both activities as well as $\mathrm{Ca}$, Fe and $\mathrm{Mn}$ in solution corresponded to its

331 complete utilization by the bacteria suggesting the precipitation of the actinides and the metals

332 (Fig 5 A, C, E and F). Previous studies on biodegradation of citric acid soil extracts containing

333 metals have shown the precipitation of the metals (Francis and Dodge 1998; Francis et al 2005).

334 Although uranium is known to form strong complexes with citric acid (Rajan and Martell.1965;

335 Francis et al. 1992), it was not detected in solution suggesting that the mineralogical form of

336 uranium in the soil was not amenable to dissolution by the citric acid concentration used in this 337 study.

338 Glucose an intermediate product of cellulose degradation is ubiquitous in nature. It is

339 used as an energy source by a wide variety of aerobic and anaerobic microorganisms in soil. In

340 glucose amended samples incubated under aerobic and anaerobic conditions, the metabolism of

341 the carbon source resulted in a decrease in $\mathrm{pH}$ due to production of organic acids with an

342 increase in alpha and beta activity in the solution. The predominant mechanism for alpha and

343 beta release into solution is due to direct enzymatic reduction of metals from higher to lower

344 oxidation state and by indirect action due to the production of organic acid metabolites and

345 lowering the $\mathrm{pH}$ of the medium. A substantial increase in Pu concentration and a slight increase

346 in Am; but no U was detected in solution. 
The increase in concentration of $\mathrm{Pu}$ in the solution phase is due to dissolution of the labile

$348 \mathrm{Pu}$ chemical species as well as $\mathrm{Pu}$ associated with calcium carbonate, and $\mathrm{Fe}-$, and $\mathrm{Mn}$-oxide

349 mineral phases by direct enzymatic reduction and by indirect the action due to organic acids and

350 acidic $\mathrm{pH}$ of the medium brought about by the anaerobic bacterial action. An increase Ca in

351 solution due to dissolution of calcium mineral phases by indirect action of the bacteria and an

352 increase in $\mathrm{Fe}$ and $\mathrm{Mn}$ in solution due to reductive dissolution of Fe- and Mn-oxides by direct

353 enzymatic action of anaerobic bacteria with the concurrent release of their associated actinides is

354 evident (Fig. $6 \mathrm{E}$ and F). XRD analysis of soil amended with glucose and incubated under

355 anaerobic conditions disclosed dissolution of calcite, dolomite, and magnetite phases due to

356 bacterial activity (Fig S2). Several studies have shown that axenic cultures of bacteria and fungi

357 solubilize $\mathrm{PuO}_{2}$, amorphous $\mathrm{Pu}(\mathrm{IV}) \mathrm{OH}$ and other chemical forms of $\mathrm{Pu}$. Under anaerobic

358 conditions reductive dissolution of amorphous $\mathrm{Pu}(\mathrm{IV})$ to $\mathrm{Pu}(\mathrm{III})$ by anaerobic bacteria has been

359 reported (Russin et al. 1994; Neu et al. 2005; Boukhalfa et al. 2007; Ohnuki et al. 2007; Francis

360 et al. 2008).

361 The speciation of $\mathrm{Pu}$ at different contaminated sites varies according to the site and the

362 waste stream (Bondietti, and Tamura, 1980; Cleveland, and Rees, 1981; Penrose, et al 1990;

363 Santschi, et al. 2002; Dai, et al. 2005; Noviko, et al. 2006; Clark, et al. 2006). The presence of

364 viable microbial populations in surficial and subsurface environments contaminated with

365 radionuclides clearly suggests that, under appropriate conditions, microbial activity potentially

366 can affect the chemical form and solubility of $\mathrm{Pu}$ and other radionuclides in several ways. These

367 include the oxidation-reduction reactions that affect their valence state and solubility; changes in

$368 \mathrm{pH}$ that affect the ionic state and their solubility; dissolution, and leaching by microbial

369 metabolites and decomposition products, such as organic acid metabolites or the production of 
370 specific sequestering agents such as siderophores; the remobilization of coprecipitated $\mathrm{Pu}$.

371 Microbes may contribute to generating and/or destabilizing Pu colloids and that microbial cells

372 may act as colloidal particles and thus facilitate radionuclide transport.

373 Dissolution of Pu from contaminated soil by microbes is influnced by the availability and

374 the type of carbon source, moisture, $\mathrm{pH}$, and other environmental factors particularly in nutrient

375 limiting arid or semi-arid environments. Clearly, information is needed on the seasonal variations

376 such as wet and dry cycles that regulate microbial processes and $\mathrm{Pu}$ speciation and its interaction

377 in complex soil system to fully understand its long-term fate and transport in the environment.

378

379 5. Conclusions

380

381 Plutonium was the predominant actinide solubilized by indigenous microbial activity in a 382 contaminated soil amended with citric acid or glucose and incubated under aerobic or anaerobic 383 conditions. Citic acid solubilized actinides and metals and soil mineral phases with the formation 384 of actinide- and metal-citrate complexes. Biodegradation of citric acid increased solution $\mathrm{pH}$ 385 with concomitant release of the actinides and metals resulting in their precipitation. Glucose 386 metabolism by anaerobic bacteria produced low molecular weight organic acid metabolites and 387 decreased solution $\mathrm{pH}$ causing dissolution of carbonate minerals and associated actinides; as well 388 as reductive dissolution of $\mathrm{Fe}$ - and Mn-oxide phases and releasing those actinides associated 389 with them. These results suggest that under appropriate environmental conditions 390 microorganisms affect the dissolution of actinides from contaminated environments. 
We thank P. Nico, Advanced Light Source, LBNL for STXM analysis of the soil sample

395 at the beam line MES 11.0.2; K. Czerwinski, UNLV for the soil sample from NTS, and A.

396 Woodhead, BNL for editorial help. This research was funded by the Office of Biological and

397 Environmental Research (OBER), Office of Science, U. S. Department of Energy, under contract

398 No. DE-SC0012704.

\section{Literature Cited}

401

402 Amy, P. S.; Haldeman, D. L.; Ringelberg, D.; Hall, D. H.; Russell, C. 1992. Comparison of 403 Identification systems for classification of bacteria isolated from water and endolithic habitats within the deep subsurface. Appl. Environ. Microbiol. 58: 3367-3373.

Au, F.H.F. and Leavitt, V.D. 1982. The Soil Microbiota of Area 13 of the Nevada Test Site. The Radioecology of Transuranics and Other Radionuclides in Desert Ecosystems. Howard, W.A. and Dunaway, P.B.; eds. NVO-224. 201-242. Las Vegas, Nevada: U.S. Department of Energy, Nevada Operations Office.

Barnhart, B.J.; Campbell, E. W.; Martinez, E.; Caldwell, D. E.; Hallett, R. 1980. Potential microbial impact on transuranic wastes under conditions expected in the waste isolation pilot plant (WIPP). Los Alamos National Laboratory, LA-8297-PR.

Bondietti, E. A.; Tamura, T. 1980. Physicochemical associations of plutonium and other actinides in soils. Transuranic elements in the environment. U. S. Department of Energy, NTIS; DOE/TIC-22800, p. 273.

Boukhalfa, H., G.A. Icopini, S.D. Reilly and M.P. Neu. 2007. Plutonium(IV) reduction by the metal-reducing bacteria Geobacter metallireducens GS-15 and Shewanella oneidensis MR-1. Appl. Environ. Microbiol. 73: 5897-5903.

Brainard, J. R.; Strietelmeier, B.A.; Smith, P.H.; Unkefer, P.J.; Barr, M.E.; Ryan, R.R. 1992, Actinide binding solubilization by microbial siderophores. Radiochim. Acta, 58/59: 357-363. 
Buesseler, K.O.; Kapalan, D. I.; Dai, M.; Pike, S. 2009. Source-dependent and sourceindependent controls on plutonium oxidation state and colloid associations in groundwater. Environ. Sci. Technol. 43: 1332-1328.

Clark, D.L.; Janecky, D.R.; Lane, L.J. 2006. Science-based cleanup of Rocky Flats. Phys. Today, 59: 34-40.

Cleveland, J. M.; Rees, T. F. 1981. Characterization of plutonium in Maxey Flats radioactive trench leachates. Science, 212: 1506-1509.

Dai, M.; Buesseler, K.O.; Pike, S. M. 2005. Plutonium in groundwater at the 100K-Area of the

EML Procedures Manual, HASL-300, 28th Edition, Volumes I and II. N. A. Chieco (Editor): Available from: NTIS, Springfield, VA 22161, Product No. PB97-162549; www.eml.doe/procman/intro.htm (1970).

Francis, A. J., C. J. Dodge. 1998. Remediation of soils and wastes contaminated with uranium and toxic metals. Environ Sci. Technol. 32: 3993-3998.

Francis, A.J., C.J. Dodge, and J.B. Gillow. 1992. Biodegradation of metal citrate complexes and implications for toxic-metal mobility. Nature 356:140-142.

Francis, A.J.; C.J. Dodge; J.A. McDonald; and G.P. Halada. 2005. Decontamination of uranium contaminated steel surfaces by hydroxycarboxylic acids with uranium recovery. Environ. Sci. Technol. 39: 5015-5021.

Francis, A. J., Gillow, J. B.; Dodge, C. J.; Dunn, M.; Mantione, K.; Strietelmeier, B. A.; PansoyHjelvik, M.E.; Papenguth, H.W. 1998. Role of microbes as biocolloids in the transport of actinides from a deep underground waste repository. Radiochim. Acta, 82: 347-354.

Francis, A. J.; Dodge, C.J. Gillow, J.B. 2008. Reductive dissolution of Pu(IV) by Clostridium sp. under anaerobic conditions. Environ. Sci. Technol. 42: 2355-2360.

Francis, A.J. 2007. Microbial mobilization and immobilization of plutonium. J. Alloys Compd. 444-445: 500-505.

Francis, A.J.; Dodge, C.J.; Gillow, J.B. 2006. Biotransformation of plutonium complexed with citric acid. Radiochim. Acta 94: 731-737.

Francis, A.J.; Dodge, C.J.; Ohnuki, T. 2007. Microbial transformations of plutonium. J. Nucl. Radiochem. Sci. 8: 121-126. 
Gromov, V.V.; Domamov, M. M.; Poov, I.B.; Ivanov, V.V. 2001. Effect of bacteria on plutonium behavior in seawater. Radiochemistry 43: 95-96.

452 Haldeman, D.L.; Amy, P.S. 1993. Bacterial heterogeneity in deep subsurface tunnels at Rainier Mesa, Nevada Test Site. Microbial Ecol., 25: 185-194.

Hoeffner, S. L.; Navratil, J.D.; Torrao, G.; Smalley, R. 2005. Evaluation of Remediation Technologies for Plutonium Contaminated

Soil. http://www.netl.doe.gov/publications/proceedings/00/ind_part00/emp12.pdf

Horn, J.M.; Masterson, B.A.; Rivera, A.; Miranda, A.; Davis, M.A.; Martin, S. 2004. Bacterial growth dynamics, limiting factors, and community diversity in a proposed geological nuclear waste repository environment. Geomicrobiol. J. 21: 273-286.

ICDD 2005. Powder Diffraction File, International Centre for Diffraction Data, edited by Frank McClune, 12 Campus Boulevard, Newton Square, Pennsylvania.

Johnson J.E; Svalberg, S.; Paine, D. 1974. The study of plutonium in aquatic systems of the Rocky Flats Environs", Final Technical Report Contract No. 41493-F, Dow Chemical Company Rocky Flats Division, Golden, Colorado, Colorado State University, Fort Collins, Colorado.

Kersting, A.B. 2013. Plutonium transport in the environment. Inorg. Chem. 52:3533-3546.

Kersting, A.B.; Efurd, D.W.; Finnegan, D.L.; Rokop, D.K.; Smith, D.K.; Thomson, J.L. 1999. Migration of plutonium in groundwater at the Nevada Test Site. Nature 397: 56-59.

Neu, M. P.; Icopini, G.A.; Boukhalfa, H. 2005. Plutonium speciation affected by environmental bacteria. Radiochim. Acta 93: 705-714.

Neu, M. P.; Ruggiero, C. E.; Francis, A. J. 2002. Bioinorganic Chemistry of Plutonium and Interactions of Plutonium with microorganisms and Plants. In "Advances in Plutonium Chemistry 1967-2000" D. Hoffman (ed), pp. 169-211. ANS, La Grange Park Illinois and University Research Alliance, Amarillo, Texas.

Nevada Test Site Annual Site Environmental Report-2002. DOE/NV/11718-842, Bechtel Nevada, National Nuclear Security Administration, Nevada Site Office, October, 2003. www.nv.doe.gov/library/publications/NTSER/DOENV_25946_259_AttachA.pdf.

Nitsche, H.; Lee, S.C.; Gatti, R.C. 1988. Determination of plutonium oxidation states at trace levels pertinent to nuclear waste disposal. J. Radioanal. Nucl. Chem. 124: 171-185. 
Noviko, A.P.; Kalmykov, S.N.; Utsunomyia, S.; Ewing, R.C.; Horreard, F.; Merkulov, A.; Clark, S.B.; Tkachev, V. V.; Myasoedov. B. F. 2006. Colloid transport of plutonium in the FarField of the Mayak Production Association, Russia. Science 314: 638-641.

Ohnuki, T.; Yoshida, T.; Ozaki, T.; Kozai, N.; Sakamoto, F.; Nankawa, T.; Suzuki, Y.; Francis, A.J. 2007. Chemical speciation and association of plutonium with bacteria, kaolinite clay, and their mixture. Environ. Sci. Technol. 41: 3134-3139.

Papelis, C.; Jacobsen, R.L.; Miller, F.L.; Shaulis, L.K. 1996. Evaluation of Technologies for Volume Reduction of Plutonium-Contaminated Soils from the Nevada Test Site, DOE/NV/10845-57, US DOE Nevada Operations Office, June, 1996. http://www.dri.edu/Publications/45139.pdf

Penrose, W.R.; Polzer, W.L.; Essington, E.H.; Nelson, D.M.; Orlandini, K.A. 1990. Mobility of plutonium and americium through shallow aquifer in a semiarid region. Environ. Sci. Technol. 24: 228-234.

Rajan, K.S. and A.E. Martell. 1965. Equilibrium studies of uranyl complexes: III. Interaction of uranyl ion with with citric acid. Inorg. Chem. 4: 462-469.

Renshaw, J.C., N. Law, A. Geissler, F.R. Livens, J.R. Lloyd. 2009. Impact of the F(III)-reducing bacteria Geobacter sulfurreduens and Shewanella oneidensis on the speciation of plutonium. Biogeochemistry 94:191-196.

Rusin, P.A.; Quintana, L.; Brainard, J.R.; Strietelmeier, B.A.; Tait, C.D.; Ekgerg, S.A.; Palmer, P.D.; Newton, T.W.; Clark, D.L. 1994. Solubilization of plutonium hydrous oxide by ironreducing bacteria. Environ. Sci. Technol. 28: 1686-1690.

Santschi, P.H.; Roberts, K.A.; Guo, L. 2002. Organic nature of colloidal actinides transported in surface water environments. Environ, Sci. Technol. 36: 3711-3719.

Tessier, A.; Rapin, F.; Carignan, R. 1985. Trace metals in oxic lake sediments: possible adsorption onto iron oxyhydroxides. Geochim. Cosmochim. Acta 49: 183-194.

Turner, M.; Rudin, M.; Cizdziel, J.; Hodge, V. 2003. Excess plutonium in soil near the Nevada Test Site, USA. Environ. Pollut. 125: 193-203.

508 Nevada Test Site: Mechanism for radionuclide transport. Environ. Sci. Technol. 43: 1283$509 \quad 1298$. 
510 Walker J. B.; P.J. Liebendorfer. 1998. Long-term stewardship at the Nevada Test Site - (NTS) 511 1998. http://www.state.nv.us/nucwaste/nts/steward.htm.

512 Wildung, R. E., Garland, T. R. Rogers, J. E. M. 1987. Plutonium interactions with soil microbial 513 metabolites: Effect on plutonium sorption by soil. DOE Symp. Ser., 59, pp. 1-25.

514 Wildung, R.E.; Garland, T. R. 1980. The relationship of microbial processes to the fate and 515 behavior of transuranic elements in soils, plants, and animals, In Transuranic Elements in the 516 Environment, pp. 300-335, (ed.) W.C. Hanson. DOE/TIC-22800. Technical Information 517 Center/US Department of energy, Washington, DC, 1980.

518 Xu, C.; Santschi, P.H.; Zhong, J.Y.; Hatcher, P.G.; Francis, A.J.; Dodge, C.J.; Roberts, K.A.; 519 Hung, C.-C.; Honeyman, B.D. 2008. Colloidal cutin-like substances cross-linked to 520 siderophore decomposition products mobilizing plutonium from contaminated soils. Environ. 521 Sci. Technol. 42: 8211-8217.

522

523

524 
Table 1. Alpha activity and concentration in NTS soil

530

\begin{tabular}{lll}
\hline Isotope & $\begin{array}{l}\text { Activity } \\
(\mathrm{nCi} / \mathrm{g})\end{array}$ & $\begin{array}{l}\text { Concentration } \\
(\mu \mathrm{g} / \mathrm{g})\end{array}$ \\
\hline $\mathrm{U} 233 / 234$ & $<0.18$ & $<6.1 \times 10^{-2}$ \\
$\mathrm{U} 235 / 236$ & $<0.15$ & $<3.6 \times 10^{1}$ \\
$\mathrm{U} 238$ & $<0.14$ & $<4.2 \times 10^{2}$ \\
$\mathrm{Am} \mathrm{241}$ & $3.8 \pm 0.7$ & $1.1 \times 10^{-3}$ \\
$\mathrm{Pu} 238$ & $0.44 \pm 0.02$ & $2.6 \times 10^{-5}$ \\
$\mathrm{Pu} 239 / 240$ & $69.2 \pm 6.5$ & $1.1 \times 10^{-1}$ \\
Total & $<75$ & $\mathrm{ND}$ \\
\hline
\end{tabular}

531 ND- not determined; Errors represent $2 \sigma$.

$532 \mathrm{U}$ result is less than the sample detection limit.

533

534

535

536

537

538

539

540 
Table 2. Extraction of radionuclides from NTS soil

\begin{tabular}{lllll}
\hline \multirow{2}{*}{ Treatment } & \multirow{2}{*}{ Activity } & Suspension & \multicolumn{2}{c}{$\begin{array}{c}\text { Supernatant } \\
\end{array}$} \\
\cline { 3 - 4 } & & \multicolumn{3}{c}{$\mathrm{kcpm} / \mathrm{g}$ soil } \\
\cline { 3 - 4 } Water & $\alpha$ & $62.9 \pm 0.8$ & $11.7 \pm 3.0$ & $0.07 \pm 0.01$ \\
& $\beta$ & $30.2 \pm 3.7$ & $0.17 \pm 0.02$ & $0.04 \pm 0.01$ \\
Citric acid (0.1 M) & $\alpha$ & $72.0 \pm 9.4$ & $18.7 \pm 0.5$ & $7.28 \pm 1.86$ \\
& $\beta$ & $23.5 \pm 7.5$ & $0.46 \pm 0.05$ & $0.36 \pm 0.08$ \\
& & & & \\
Nitric acid $(1 \mathrm{M})$ & $\alpha$ & $98.0 \pm 4.2$ & $27.2 \pm 1.6$ & $10.8 \pm 0.5$ \\
& $\beta$ & $39.8 \pm$ & $0.76 \pm 0.03$ & $0.48 \pm 0.3$ \\
\hline
\end{tabular}


554 Table 3. Effect of adding citric acid or glucose on gas production, $\mathrm{pH}$, Eh, and iron in NTS soil 555 incubated for 36 days.

556

\begin{tabular}{llllll}
\hline Treatment & $\begin{array}{l}\text { Pressure } \\
(\mathrm{psig})\end{array}$ & $\mathrm{pH}$ & $\begin{array}{l}\text { Eh } \\
(\mathrm{mV})\end{array}$ & $\begin{array}{l}\text { Total Iron } \\
(\mathrm{mM})\end{array}$ & $\begin{array}{l}\text { Ferrous ion } \\
(\mathrm{mM})\end{array}$ \\
\hline Aerobic & & & & & \\
Unamended & $\mathrm{NA}$ & $9.00 \pm 0.02$ & $607 \pm 11$ & $0.013 \pm 0.002$ & $<0.01$ \\
Citrate $+\mathrm{N}$ & $\mathrm{NA}$ & $7.70 \pm 0.05$ & $170 \pm 24$ & $0.051 \pm 0.030$ & $<0.01$ \\
Glucose $+\mathrm{N}$ & $\mathrm{NA}$ & $5.23 \pm 0.28$ & $337 \pm 13$ & $0.128 \pm 0.045$ & $0.092 \pm 0.040$ \\
Anaerobic & & & & & \\
Unamended & $<1$ & $9.30 \pm 0.05$ & $531 \pm 3$ & $<0.01$ & $<0.01$ \\
Citrate $+\mathrm{N}$ & $<1$ & $7.43 \pm 0.03$ & $-306 \pm 24$ & $<0.01$ & $<0.01$ \\
Glucose $+\mathrm{N}$ & $7 \pm 1$ & $4.83 \pm 0.05$ & $-210 \pm 18$ & $1.63 \pm 0.14$ & $1.26 \pm 0.43$ \\
\hline
\end{tabular}

NA- not applicable; Error bars \pm 1 SEM 
574

575

576

577

578

579 580

\begin{tabular}{llc}
\hline \multirow{2}{*}{ Sample } & \multicolumn{2}{c}{ Activity $(\mathrm{cpm} / \mathrm{ml})$} \\
\cline { 2 - 3 } Unfiltered & $\alpha 940 \pm 60$ & $86.8 \pm 12.4$ \\
$0.4 \mu \mathrm{m}$ filtered & $126 \pm 3$ & $8.8 \pm 0.1$ \\
$0.2 \mu \mathrm{m}$ filtered & $139 \pm 17$ & $10.1 \pm 0.9$ \\
$0.03 \mu \mathrm{m}$ filtered & $116 \pm 5$ & $9.1 \pm 0.1$ \\
$0.01 \mu \mathrm{m}$ filtered & & 8.9 \\
$0.001 \mu \mathrm{m}$ filtered & 106 & $7.1 \pm 2.7$
\end{tabular}

Table 4. Sequential filtration of actinides in glucose amended sample incubated anaerobically. 


\section{Figure Legends}

Figure 1. Mineralogical association of alpha-emitting fractions in NTS soil.

Figure 2. Synchrotron-based $\mu$-x-ray fluorescence map of uranium association with minerals in NTS soil. The Ca-containing phases exhibit the closet correlation.

Figure 3. $\mu$-XANES spectrum of uranium in NTS soil. Uranium is present as tetravalent and hexavalent form. The vertical line is set to the absorption edge energy for uranium dioxide.

Figure 4. Scanning transmission x-ray microscopy (STXM) image of NTS soil particles (A). The region boxed in red consisted of $\mathrm{Fe}$ and $\mathrm{Mn}$ oxides and aluminosilicates. Plutonium was observed in this region (B) and was localized to a small area of the sample $(500 \mathrm{~nm})$.

Figure 5. Effect of adding citric acid on the mobilization of radionuclides and metals by indigenous bacteria incubated under aerobic and anaerobic conditions.

Figure 6. Effect of adding glucose on the mobilization of radionuclides and metals by indigenous bacteria incubated under aerobic and anaerobic conditions. Error bars are \pm 1 SEM. 


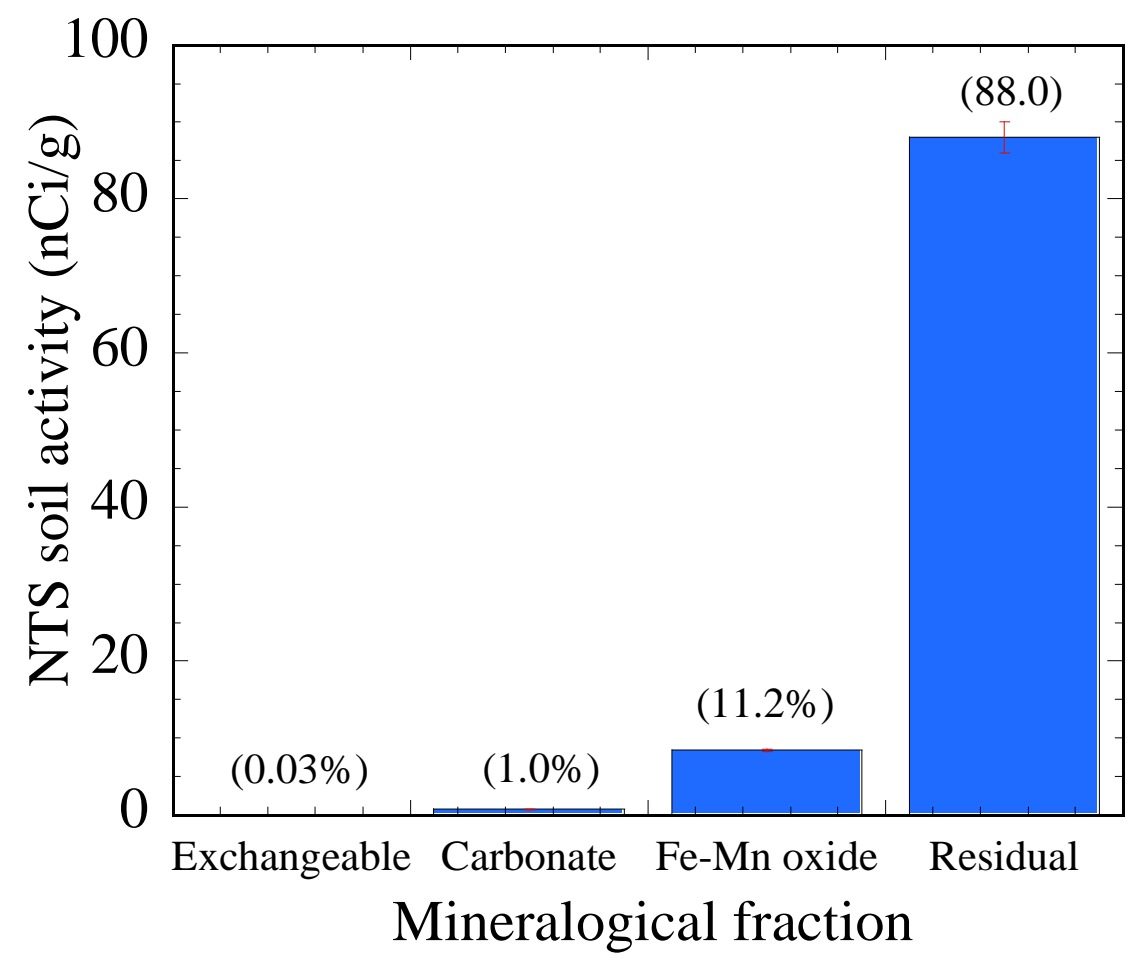

613

614 Figure 1. Mineralogical association of alpha-emitting fractions in NTS soil.

615

616

617 


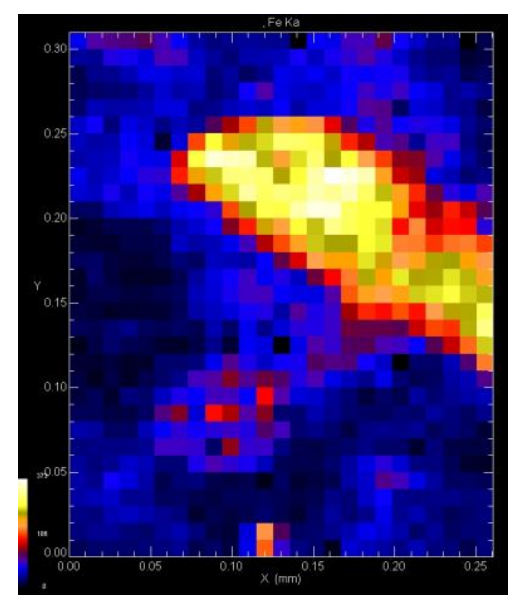

Fe $\mathrm{K}_{\alpha}$

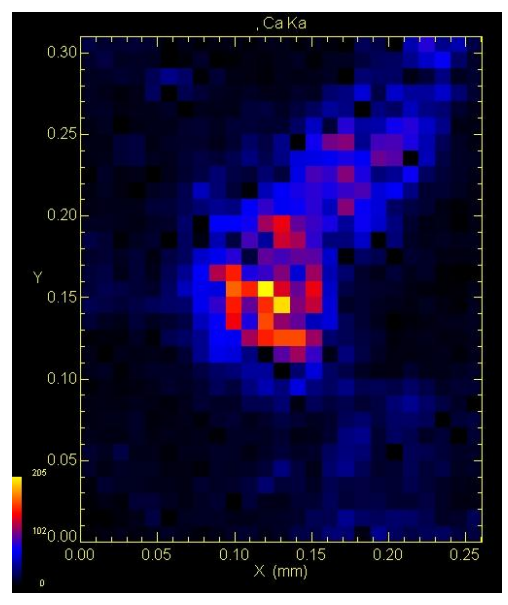

$\mathrm{Ca} \mathrm{K}_{\alpha}$

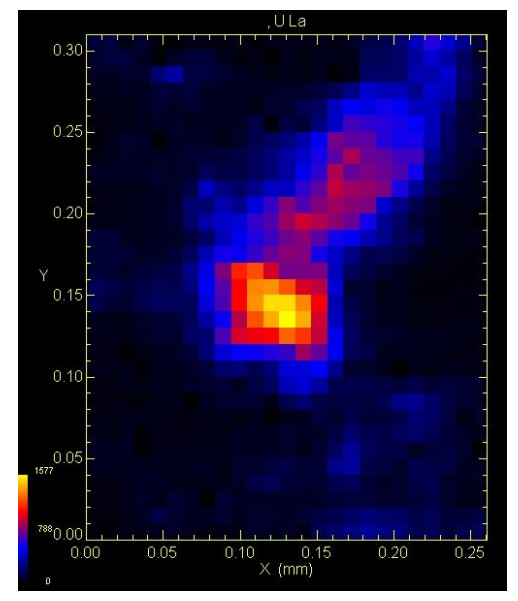

$\mathrm{UL}_{\alpha}$
620

621

622

623

624

625

626

627
Figure 2. Synchrotron-based $\mu$-x-ray fluorescence map of uranium association with minerals in NTS soil. The Ca-containing phases exhibit the closet correlation. 


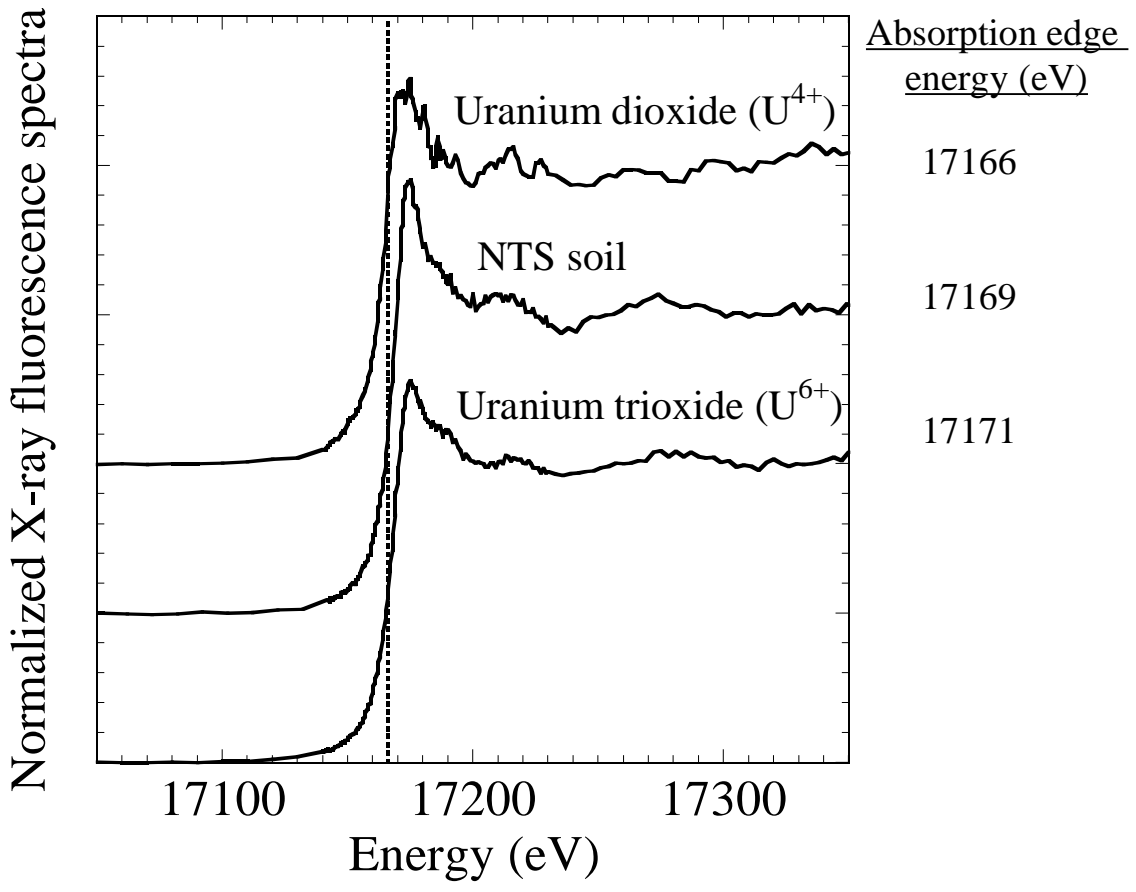

629

630 Figure 3. $\mu$-XANES spectrum of uranium in NTS soil. Uranium is present as tetravalent and 631 hexavalent form. The vertical line is set to the absorption edge energy for uranium dioxide.

632

633

634 


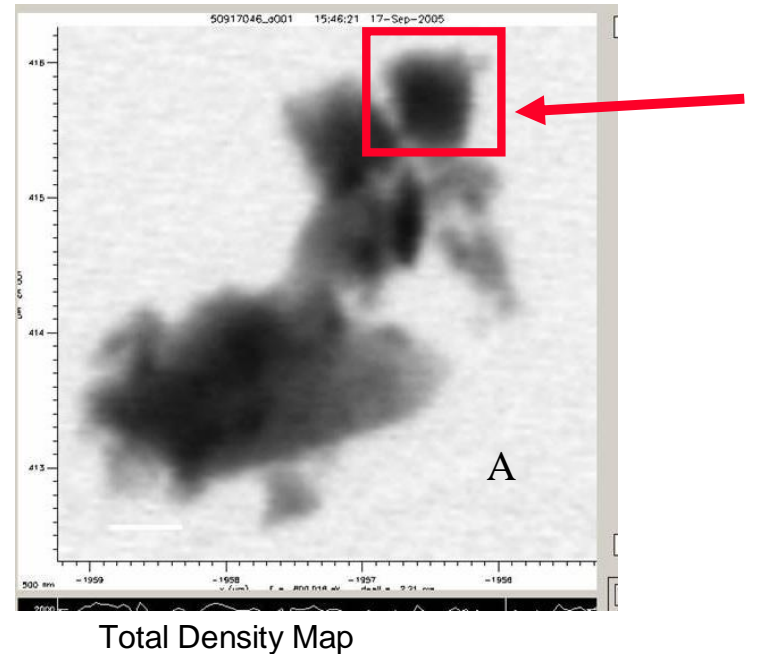

Image @ 800 eV (4 x 4 um)

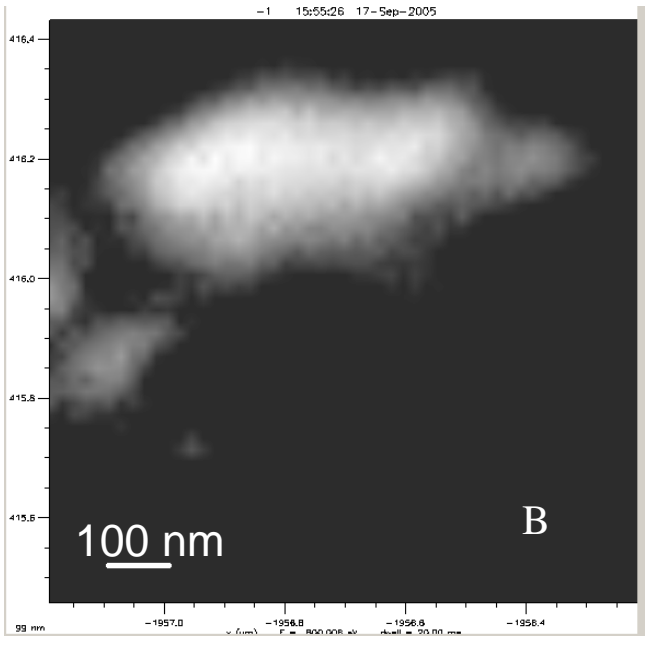

Pu map
637

638

639

640

641

642

643

644

645 

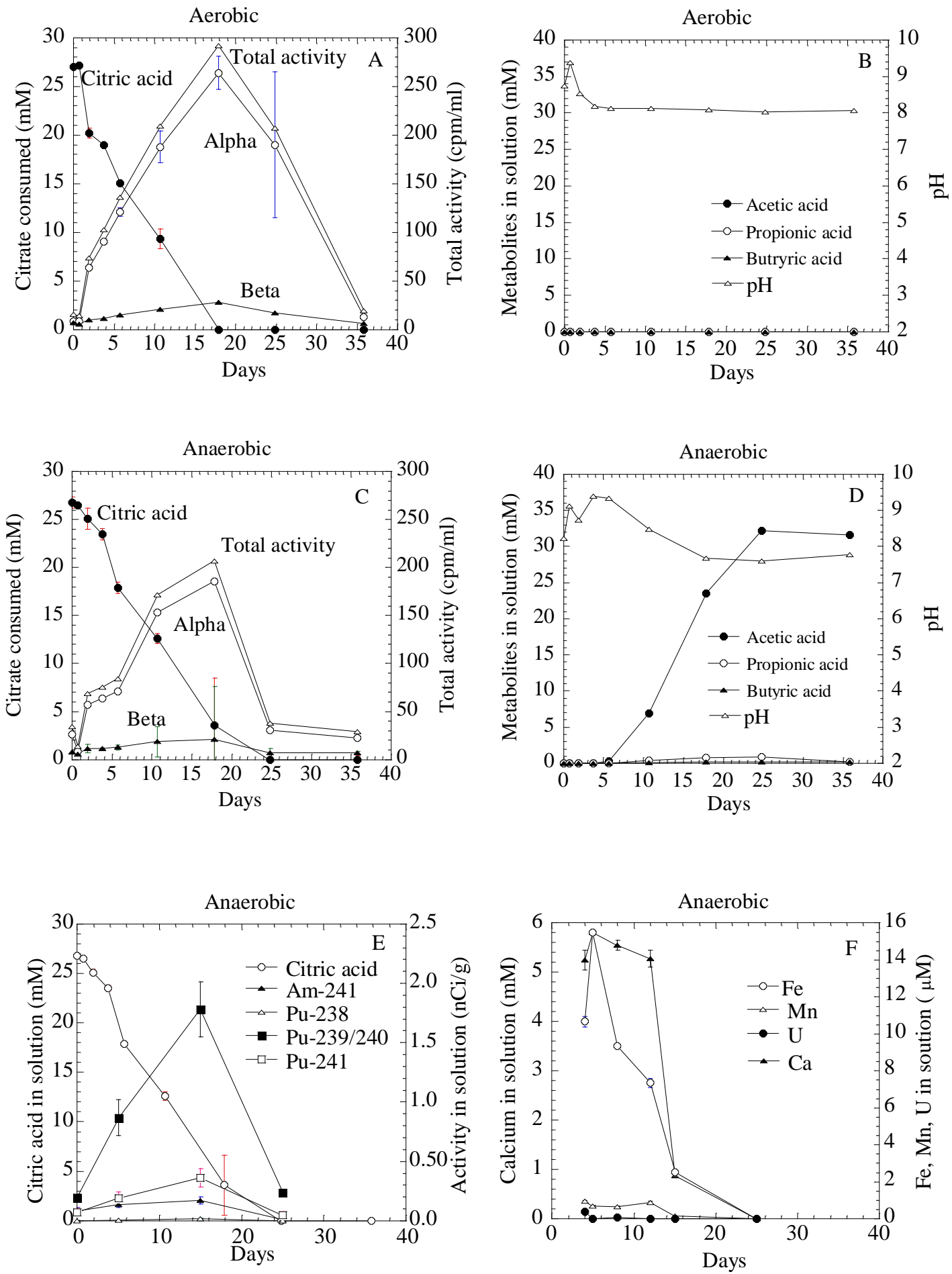

648

649

650

651

652 

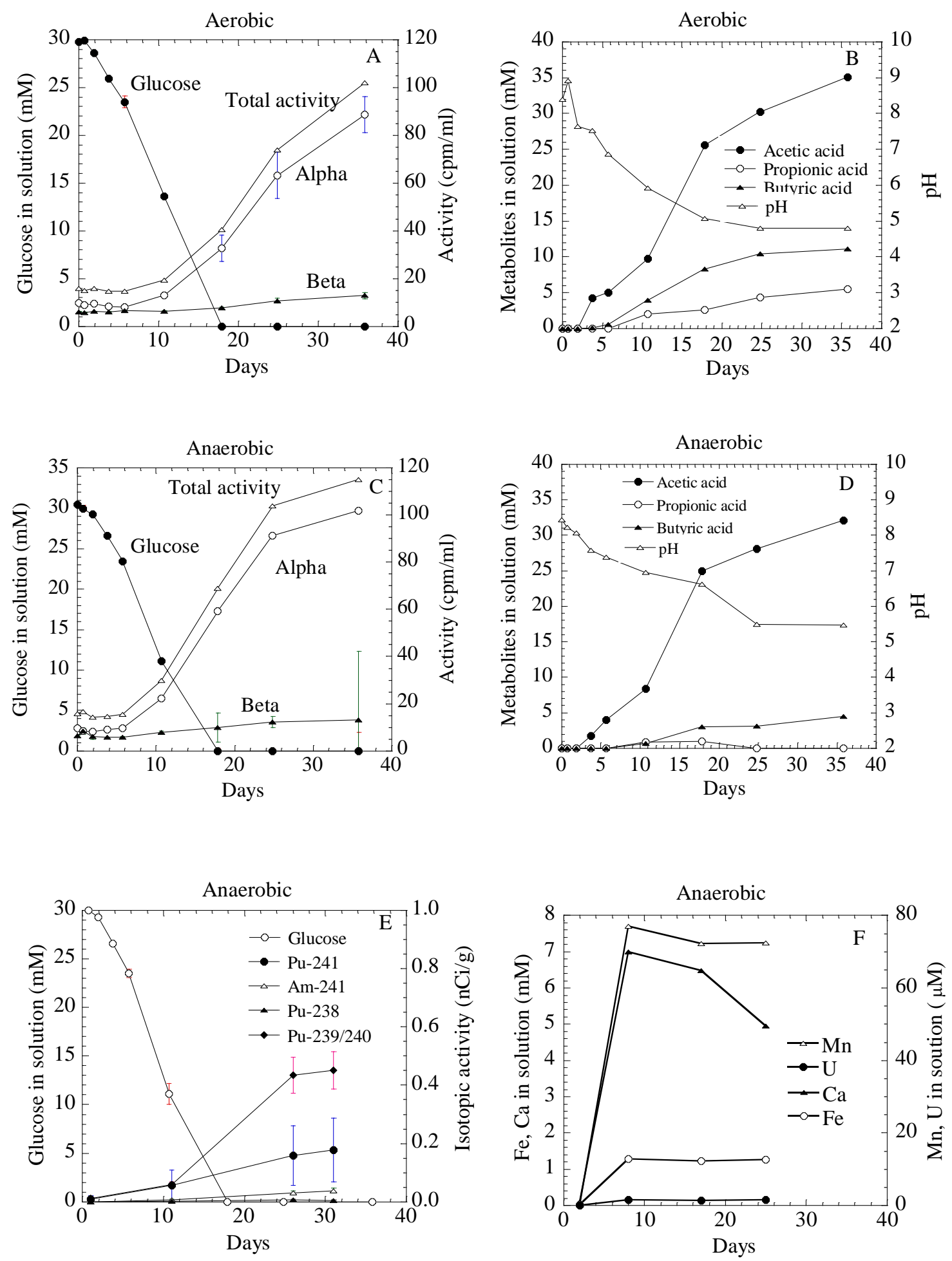

655 Figure 6. Effect of adding glucose on the mobilization of radionuclides and metals by indigenous 656 657 